ISSN 0258-7122

Bangladesh J. Agril. Res. 34(3) : 443-448, September 2009

\title{
EFFECT OF DEHAULMING ON YIELD OF SEED POTATOES
}

\author{
A. A. MAHMUD ${ }^{1}$, SAJEDA AKHTER ${ }^{2}$, M. J. HOSSAIN ${ }^{3}$ \\ M. K. R. BHUIYAN ${ }^{4}$ AND M. A. HOQUE ${ }^{5}$
}

\begin{abstract}
The yield of seed size tubers was assessed in five standard potato cultivars (Cardinal, Multa, Ailsa, Heera, and Dheera) in relation to dates of dehaulming (65, 70, and 80 days after planting) in a Seed Potato Production Farm, Debijong, Panchagarh during 1996-97 and 1997-98. Dehaulming at 70 days gave maximum seed size tubers (19.75 t/ha $\approx 76 \%$ ) but significantly identical to 75 days $(19.56 \mathrm{t} / \mathrm{ha} \approx 70 \%)$ and 80 days (18.69 t/ha $\approx 63 \%)$. Considering all the parameters studied, the performance of Heera proved to be best among the cultivars grown. Among the cultivars, the maximum seed tuber yield was recorded from Cardinal at 80 DAP followed by Heera and Cardinal at 70 DAP, Dheera and Ailsa at 75 DAP. In general, most of the cultivars gave the maximum seed tuber yield when the crop was dehaulmed at 70 and 80 DAP and the lowest from 65 DAP.
\end{abstract}

Key Words: Dehaulming, potato, seed production.

\section{Introduction}

The national average yield of potato in Bangladesh is around $12.60 \mathrm{t} / \mathrm{ha}$, which is lower compared to neighbouring country, India (16 t/ha). The major limiting factor for this low yield of potato is the non-availability of quality seed potatoes. In Bangladesh, about 200 thousand tons of seed potatoes are planted annually. Of them, only 7 thousand tons of certified grade are produced and supplied by the government agency. Another 7 thousand tons are produced and distributed by other agencies (private and NGO sector). Thus, it is calculated that only $7.0 \%$ of the total seed requirement are of good quality and the rest $93.0 \%$ are of poor quality. This figure indicates that there is a tremendous demand of quality seed in the country.

Seed production agencies in the country followed a standard method which involved pre-foundation seeds (local or imported) $\rightarrow$ foundation seed (local or imported) $\rightarrow$ certified seed-I (local/imported) $\rightarrow$ Certified-II (local) $\rightarrow$ distribution to farmers. Seed production is a highly technical matter which needs careful attention in all stages like date of planting, spacing, fertilization, top-dressing, irrigation, weeding, earthing up, spraying of pesticides, date of dehaulming, harvesting, etc. Removal of above ground part of potato crop is referred to dehaulming. The existing ratio of seed potato yield to total yield is about 0.6:1.0

${ }^{1,2285}$ Tuber Crops Research Centre, BARI, Joydebpur, Gazipur, ${ }^{3}$ Research Wing, BARI, Gazipur, ${ }^{4}$ RHRS, Jaintapur, Sylhet, Bangladesh. 
(Anon., 1994) which could be improved through agronomic management. Hence, the experiment was undertken to increase the proportion of seed size tuber through dehaulming at appropriate time.

\section{Materials and Method}

The experiment was conducted at the Seed Potato Production Farm, Debiganj, Panchagarh of AEZ 3 during 1996-97 and 1997-98. The treatments were 5 (five) cultivars, such as Cardinal, Multa, Heera, Ailsa, and Dheera and 4 (four) dates of dehaulming $(65,70,75,80$ DAP). Seed size (40-60g) whole tubers were planted at $60 \mathrm{~cm}$ x $30 \mathrm{~cm}$ spacing on 18 November 1996 and 15 November 1997. The unit plot size was $3 \mathrm{~m} \times 3 \mathrm{~m}$. The initial nutrient status of soils of the experimental plots was $17,9,3$, and $6 \mu \mathrm{g} / \mathrm{ml}$ of $\mathrm{NH}_{4}-\mathrm{N}, \mathrm{P}, \mathrm{Zn}$, and $\mathrm{S}$, respectively, and 0.10 , 1.9 , and $0.65 \mathrm{meq} / 100 \mathrm{ml}$ of $\mathrm{K}, \mathrm{Ca}$, and $\mathrm{Mg}$, respectively, and organic matter was $0.73 \%$. The $\mathrm{pH}$ of the soil was 6.4 . The soil type of the experimental site was sandy loam and the crops were fertilized @ 250 kg urea, 220 kg TSP, 200 kg MP, $120 \mathrm{~kg}$ Gypsum and $6 \mathrm{~kg}$ boric acid per hectare. Full dose of TSP, MP, Gypsum, boric acid, and one half of urea were applied during land preparation and the rest one half of urea was side dressed during first earthing up and weeding operations, 30 days after planting (DAP). The crops were irrigated four times and were regularly sprayed at 10 days interval with $0.2 \%$ desis. The experiment was conducted in a factorial randomized complete block design replicated thrice. The crops were harvested after 10 days of haulms cutting. Data on seed yield of seed tubers and yield attributes were recorded and analyzed statistically.

\section{Results and Discussion}

\section{Effect of cultivars on seed yield}

The cultivars did not show any significant variation for different parameters over the years so the pooled data were done and are presented in Table 1-3. The cultivars differed significantly for most of the parameters studied (Table 1). The cv. Cardinal showed the highest number of tubers per hill (14.56) which was statistically superior to all other treatments. The other treatments were statistically at par but lower than the previous one. The cv. Heera gave the maximum tuber weight per hill (533.50 g), which is corresponding to the highest total yield (29.54 t/ha) and seed tuber yield (19.27 t/ha). The highest total yield was recorded from cv. Heera, but seed yield was not significantly influenced through non-seed yield from the same variety. In terms of seed tuber percentage, Multa was the best (72.60\%) followed by Ailsa (71.82\%) and Dheera $(71.74 \%)$. A similar trend in reverse order for non-seed portion was observed, where Multa was the least (1:0.377) and Heera the highest (1:533). 
Table 1. Seed yield of five potato cultivars as influenced by dates of haulm cutting during 1996-97 and 1997-98 (pooled).

\begin{tabular}{l|c|c|c|c|c|c|c|c}
\hline Cultivars & $\begin{array}{c}\text { Tubers/ } \\
\text { hill }\end{array}$ & $\begin{array}{c}\text { Wt. of } \\
\text { tubers/ } \\
\text { hill (g) }\end{array}$ & $\begin{array}{c}\text { Yield } \\
\text { (t/ha) }\end{array}$ & $\begin{array}{c}\text { Seed } \\
\text { yield } \\
\text { (t/ha) }\end{array}$ & $\begin{array}{c}\text { Percent } \\
\text { seed } \\
\text { tuber }\end{array}$ & $\begin{array}{c}\text { Yield of } \\
\text { non-seed } \\
\text { tuber (t/ha) }\end{array}$ & $\begin{array}{c}\text { Percent } \\
\text { non-seed } \\
\text { tuber }\end{array}$ & $\begin{array}{c}\text { Ratio } \\
\text { (seed: non- } \\
\text { seed) }\end{array}$ \\
\hline Cardinal & 14.56 & 491.50 & 27.22 & 18.88 & 69.36 & 8.34 & 30.64 & 0.442 \\
Multa & 13.28 & 447.00 & 24.81 & 18.01 & 72.60 & 6.80 & 27.40 & 0.377 \\
Heera & 12.87 & 533.50 & 29.54 & 19.27 & 65.23 & 10.27 & 34.77 & 0.533 \\
Ailsa & 12.78 & 450.00 & 24.98 & 17.94 & 71.82 & 7.04 & 28.18 & 0.392 \\
Dheera & 13.27 & 443.00 & 24.61 & 17.65 & 71.74 & 6.95 & 28.26 & 0.394 \\
\hline LSD (5\%) & 1.11 & 36.85 & 2.36 & 1.54 & 2.64 & 1.02 & 2.21 & 0.09 \\
\hline
\end{tabular}

\section{Effect of haulm cutting on seed yield}

The number of tubers per hill ranged from 12.08 to 15.06 (Table 2). However, this parameter is not related to haulm cutting because tuber formation in potato is almost completed within 50 days (Beukema and Zaag, 1990). The weight of tubers per hill increased gradually. It was $384.20 \mathrm{~g}$ when haulm was cut at 65 DAP, which arose upto $533.00 \mathrm{~g}$ at 80 DAP. The result of 80 DAP was statistically similar to 75 DAP (505.60 g). Haulms cut at 75 and 80 DAP gave statistically almost similar tuber yield (28.02 and $29.57 \mathrm{t} /$ ha, respectively, (Table 2). It was 26.02 tons for $70 \mathrm{DAP}$ and the least was for $65 \mathrm{DAP}(21.30 \mathrm{t} / \mathrm{ha})$. The maximum seed yield was $19.75 \mathrm{t} / \mathrm{ha}$ ) at $70 \mathrm{DAP}$, which was statistically identical to 75 (19.56 t/ha) and 80 (18.69 t/ha) DAP. The seed yield at 65 DAP was the poorest (15.40 t/ha). The percentage of seed yield for 65 (72\%) and 75 (\%) DAP was statistically identical, while the least was for 80 DAP (63\%) (Table 2). Haulm cut at 80 DAP produced the maximum of 10.89 t/ha non-seed tuber, which was equivalent to $37 \%$. The yield of non-seed tuber ranged from $5.90 \mathrm{t} / \mathrm{ha}$ at $65 \mathrm{DAP}$ to $8.45 \mathrm{t} / \mathrm{ha}$, which was coresponding to 28 to $30 \%$, respectively. The best ration of seed and non-seed was 1:0.318 for 70 DAP and the poorest was 1:0.583 for 80 DAP (Table 2).

The tuber weight per hill increased with age, which is obvious upto 80 days under the tropical climatic condition of Bangladesh. Under this climatic conditions, potato crop mature within 85 to 95 days (Rashid, 1974; Ahmad 1977; Hussain, 1985). On weight basis, the maximum seed yield was recorded when haulm was cut at 70 days (19.75 t/ha), but statistically identical to 75 and 80 DAP. Beside, dehaulming at 75 and 80 days produced 19.56 and 18.69 t/ha, which indicates that with plant age, tuber size increased. As such, percentage of seed size tuber decreased. A decrease in the tuber yield with delayed planting has been reported by Lal and Sahota (1990) and Gupta (1990). Compared to 75 and 
80 days, dehaulming at 65 day scored $72 \%$ seed size tuber though its total tuber yield was lower than 75 and 80 days (Tablae 2).

Table 2. Effect of dates of haulm cutting on seed yield of potato during 1996-97 and 1997-98 (Pooled).

\begin{tabular}{l|c|c|c|c|c|c|c|c}
\hline $\begin{array}{c}\text { Days to } \\
\text { haulm } \\
\text { cutting }\end{array}$ & $\begin{array}{c}\text { Tubers/ } \\
\text { hill }\end{array}$ & $\begin{array}{c}\text { Wt of } \\
\text { tubers/ } \\
\text { hill (g) }\end{array}$ & $\begin{array}{c}\text { Yield } \\
\text { (t/ha) }\end{array}$ & $\begin{array}{c}\text { Seed } \\
\text { yield } \\
\text { (t/ha) }\end{array}$ & $\begin{array}{c}\text { Percent } \\
\text { seed } \\
\text { tuber }\end{array}$ & $\begin{array}{c}\text { Yield of } \\
\text { non-seed } \\
\text { tuber (t/ha) }\end{array}$ & $\begin{array}{c}\text { Percent } \\
\text { non-seed } \\
\text { tuber }\end{array}$ & $\begin{array}{c}\text { Ratio } \\
\text { (seed: non- } \\
\text { seed) }\end{array}$ \\
\hline 65 & 12.08 & 384.20 & 21.30 & 15.40 & 72.00 & 5.90 & 28.00 & $1: 0.383$ \\
70 & 15.06 & 469.20 & 26.02 & 19.75 & 76.00 & 6.28 & 24.00 & $1: 0.318$ \\
75 & 14.03 & 505.60 & 28.02 & 19.56 & 70.00 & 8.45 & 30.00 & $1: 0.432$ \\
80 & 12.31 & 533.00 & 29.57 & 18.69 & 63.00 & 10.89 & 37.00 & $1: 0.587$ \\
\hline LSD (5\%) & 1.23 & 75.32 & 2.09 & 2.91 & 2.83 & 1.31 & 2.68 & - \\
\hline
\end{tabular}

\section{Effect of interaction of cultivar and haulm cutting on seed yield}

In most of the cultivars, the number of tubers per hill for 65 and 80 DAP was the minimum and was almost similar (ranged from 10.50 to13.46 for 65 DAP and 11.68 to 13.47 for 80 DAP). While, it ranged from 13.30 to15.96 for 70 DAP and 12.02 to 16.11 for 80 DAP across the cultivars (Table 3). The weight of tubers per hill increased gradually in all the cultivars. The maximum was $598 \mathrm{~g}$ in Heera at 80 DAP and the minimum $350 \mathrm{~g}$ in Ailsa at the same duration. Similarly, tuber yield of the cultivars increased gradually from 65 DAP to 80 DAP. The cultivar Heera gave the maximum tuber yield (32.94 t/ha), which was closely followed by cv. Cardinal at 80 DAP (32.92 t/ha). The minimum yield of tuber was $19.46 \mathrm{t} / \mathrm{ha}$ in cv. Ailsa for 65 DAP. On weight basis, the cv. Cardinal gave the maximum seed yield (22.23 t/ha) at 80 DAP, closely followed by $22.12 \mathrm{t}$ in cv. Heera at 70 DAP, the minimum was $13.49 \mathrm{t}$ in cv. Dheera for 65 DAP (Table 3). On contrast, the percentage of seed yield ranged from 54.97 to 80.81 . However, the cv. Dheera at 75 DAP gave the maximum percentage of seed yield (80.81), closely followed by the cv. Multa at 70 DAP (79.70\%). For most of the cultivars, these percentage was the lowest at 65 DAP. The yield of non-seed tubers varied from $5.01 \mathrm{t} / \mathrm{ha}$ for cv. Dheera at 80 DAP to $14.94 \mathrm{t}$ for Heera at the same duration (Table 3). The maximum percentage of non-seed was produced by $\mathrm{cv}$. Heera at 80 DAP (45.03\%) closely followed by the same cv. At 75 DAP (41.14\%) and Ailsa at 80 DAP (39.74\%), while the cv. Dheera at 75 DAP was the least (19.19\%), which also gave the minimum ratio of seed to non-seed (1: 0.237$)$. The $\mathrm{h}$ value of this ratio was 1:819 for cv. Heera at 80 DAP.

It is reported that under the tropical climatic condition, tuber weight of potato cultivars increases upto 80 days and decreases slowly after 90 days (Rashid, 1974; Ahmad, 1977; Hussain 1985). With the rise of temperature in the month of late February or March, potato storage food used in reverse order from tuber to 
foliage (Beukema and Zaag, 1990). Garg et al. (1999) planted tubers on 15 April, 1 May, 1 June, and 20 June in India and haulms were cut after 75, 90, and 105 days. They recorded the maximum seed size tubers with early planting under long duration. They also recommended that late planting and short duration is also good. Akhter et al. (1998) studied bulking rate of potato cultivars and recorded 12.90, 18.92, 21.72, 27.68, and 30.11 tons tuber yield per ha after 50, $60,70,80$, and 90 days, respectively. The bulking rate of crop grown from physiologically old seed was less than that of physiologically younger seed planted on earlier dates (Wurr, 1978). In the present investigation, seeds at right physiological age from $2^{\text {nd }}$ generation tubers were used.

Table 3. Combined effect of variety and dates of haulm cutting on seed yield of potato crops during 1996-97 and 1997-98 (pooled).

\begin{tabular}{|c|c|c|c|c|c|c|c|c|c|}
\hline \multicolumn{2}{|c|}{ Treatment } & \multirow{2}{*}{\begin{tabular}{|c|} 
Tubers/ \\
hill
\end{tabular}} & \multirow{2}{*}{$\begin{array}{l}\text { Wt. of } \\
\text { tubers/ } \\
\text { hill (g) }\end{array}$} & \multirow{2}{*}{$\begin{array}{l}\text { Yield } \\
\text { (t/ha) }\end{array}$} & \multirow{2}{*}{$\begin{array}{c}\text { See } \\
\text { yield } \\
\text { (t/ha) }\end{array}$} & \multirow{2}{*}{$\begin{array}{c}\text { Percent } \\
\text { seed } \\
\text { tuber }\end{array}$} & \multirow{2}{*}{$\begin{array}{c}\text { Yield of } \\
\text { non-seed } \\
\text { tuber } \\
\text { (t/ha) }\end{array}$} & \multirow{2}{*}{$\begin{array}{c}\text { Percent } \\
\text { non-seed } \\
\text { tuber }\end{array}$} & \multirow{2}{*}{$\begin{array}{c}\text { Ratio } \\
\text { (seed: } \\
\text { non- } \\
\text { seed) }\end{array}$} \\
\hline Cultivars & $\begin{array}{l}\text { Days to } \\
\text { haulm } \\
\text { cutting }\end{array}$ & & & & & & & & \\
\hline \multirow[t]{4}{*}{ Cardinal } & 65 & 13.46 & 405 & 22.39 & 15.69 & 70.08 & 6.70 & 29.92 & 0.427 \\
\hline & 70 & 15.19 & 470 & 26.08 & 19.10 & 73.24 & 6.98 & 26.76 & 0.365 \\
\hline & 75 & 16.11 & 495 & 27.47 & 18.48 & 67.27 & 8.99 & 32.73 & 0.486 \\
\hline & 80 & 13.47 & 596 & 32.92 & 22.23 & 67.53 & 10.69 & 32.47 & 0.481 \\
\hline \multirow[t]{4}{*}{ Mulla } & 65 & 13.69 & 374 & 20.79 & 15.60 & 75.04 & 5.19 & 24.96 & 0.333 \\
\hline & 70 & 15.65 & 452 & 25.12 & 20.02 & 79.70 & 5.10 & 20.30 & 0.255 \\
\hline & 75 & 12.02 & 477 & 26.35 & 18.49 & 70.17 & 7.86 & 29.83 & 0.425 \\
\hline & 80 & 11.76 & 485 & 26.96 & 17.92 & 66.47 & 9.04 & 33.33 & 0.504 \\
\hline \multirow[t]{4}{*}{ Heera } & 65 & 11.11 & 421 & 23.38 & 17.32 & 74.08 & 6.06 & 25.92 & 0.350 \\
\hline & 70 & 15.96 & 520 & 28.66 & 22.12 & 77.18 & 6.54 & 22.82 & 0.296 \\
\hline & 75 & 13.14 & 595 & 32.94 & 19.39 & 58.86 & 13.55 & 41.14 & 0.699 \\
\hline & 80 & 11.68 & 598 & 33.18 & 18.24 & 54.97 & 14.94 & 45.03 & 0.819 \\
\hline \multirow[t]{4}{*}{ Ailsa } & 65 & 10.50 & 350 & 19.46 & 14.89 & 76.52 & 4.57 & 23.48 & 0.307 \\
\hline & 70 & 13.30 & 452 & 25.12 & 19.57 & 77.91 & 5.55 & 22.09 & 0.284 \\
\hline & 75 & 15.63 & 492 & 27.22 & 20.36 & 74.80 & 6.86 & 25.20 & 0.337 \\
\hline & 80 & 11.70 & 506 & 28.11 & 16.94 & 60.26 & 11.17 & 39.17 & 0.659 \\
\hline \multirow[t]{4}{*}{ Dheera } & 65 & 11.66 & 371 & 20.49 & 13.49 & 65.84 & 7.00 & 34.16 & 0.519 \\
\hline & 70 & 15.22 & 492 & 25.14 & 17.92 & 71.28 & 7.22 & 28.72 & 0.403 \\
\hline & 75 & 13.27 & 469 & 26.11 & 21.10 & 80.81 & 5.01 & 19.19 & 0.237 \\
\hline & 80 & 12.92 & 480 & 26.69 & 18.10 & 67.82 & 8.59 & 32.18 & 0.475 \\
\hline \multicolumn{2}{|c|}{ LSD (5\%) for C x D } & 2.01 & 123.21 & 3.64 & 3.36 & 3.54 & 1.62 & 3.02 & 0.20 \\
\hline
\end{tabular}




\section{Conclusion}

The results show that the crop should be allowed to grow 70 to 75 days for achieving the highest seed sized tuber yield as well as the number of seed tubers. Haulms can also be killed at 65 or 75 days without sacrificing much of number and seed sized tuber yield. It could expose the crop to a lesser period to diseases and pests which results in healthy seed crop.

\section{References}

Ahmad K. U. 1977. Potato production. In: Potatoes for the tropices. Mrs. Mumtaj Kamal, Bunglow No. 2, Farmgate, Dhak-15, Bangladesh. pp. 19-22.

Akhter S., M.K.R. Bhuiyan, M.A. Hoque and A. Quasem. 1998. Growth and bulking behaviour of three newly released potato varieties. Bangladesh J. Agrl. Res. 23: 97106.

Annonymous. 1994. Annual Report of Breeder Seed Production Centre, 1993-94. Breeder Seed Production Centre, Debiganj, Panchaghar. pp. 1-16.

Beukema H.P. and V.D. Zaag de. 1990. Crop ecophysiology, In: Introduction to potato production. PUDOC, Wageningen, The Netherlands. pp. 42-60.

Garg V.K., Deshraj and S. Sarjeet. 1999 Influence of dates of planting and haulms cutting on the yield of seed sized tubers in Shimla Hills. Journal of Indian Potato Association 26: 7-13.

Gupta A. 1990. Response of potato to planting and harvesting dates. Journal of Indian Potato Association 17: 195-198.

Hussain M.M. 1985. Alu Utpadayanay Pariparshikatar Provab (Influence of environment on potato production). In: Alu Utpadayan, Sangrakkhan O Babohar (Potato production, storage and utilisation). Meer Tochimon Ghani, 85/1, Kakarail, Ramna, Dhaka-2, Bangladesh, pp. 44-50.

Lal S.S. and T.S. Sahota. 1983. Effect of time of planting and lifting on tuber yield of potato in Shillong hills. Journal of Indian Potato Association 10: 129-133.

Rashid M.M. 1974. Pariparshik Chahida (Environmental demands). In: Alur Chash (Potato production), Mohammad Ibrahim, Director, Bangla Academy, Dhaka, Bangladesh.

Wurr D.C.F. 1978. Seed tuber production and management. In: the potato Crop (P.M. Haris Ed.), Chapman \& Hall, London, pp. 329-354. 